TITLE:

\title{
Ti-bridged silsesquioxanes as precursors of silica-supported titanium oxide catalysts for the epoxidation of cyclooctene
}

\section{AUTHOR(S):}

Sakugawa, Shuko; Wada, Kenji; Inoue, Masashi

\section{CITATION:}

Sakugawa, Shuko ...[et al]. Ti-bridged silsesquioxanes as precursors of silica-supported titanium oxide catalysts for the epoxidation of cyclooctene. Journal of Catalysis 2010, 275(2): 280-287

ISSUE DATE:

2010-09-22

URL:

http://hdl.handle.net/2433/131821

\section{RIGHT:}

@ 2010 Elsevier Inc.; この論文は出版社版でありません。引用の際には 出版社版をご確認ご利用ください。; This is not the published version. Please cite only the published version. 


\section{Ti-bridged Silsesquioxanes as Precursors of Silica-supported Titanium Oxide Catalysts for the Epoxidation of Cyclooctene}

Shuko Sakugawa, Kenji Wada, ${ }^{*}$ and Masashi Inoue

Department of Energy and Hydrocarbon Chemistry, Graduate School of Engineering, Kyoto University, Katsura, Nishikyo-ku, Kyoto 615-8510, JAPAN

Phone +81-75-383-2482, Fax +81-75-383-2479, e-mail wadaken @ scl.kyoto-u.ac.jp

\section{ABSTRACT:}

Silica-supported titanium oxide catalysts were prepared by the controlled calcination of Ti-bridged polyhedral oligomeric silsesquioxanes (POSS) bearing four Si-O-Ti bonds, $\operatorname{Ti}\left[\left(c-\mathrm{C}_{5} \mathrm{H}_{9}\right)_{7} \mathrm{Si}_{7} \mathrm{O}_{11}\left(\mathrm{OSiMe}{ }_{2} \mathrm{R}\right)\right]_{2}(\mathbf{1 a} ; \mathrm{R}=$ vinyl, $\mathbf{1 b} ; \mathrm{R}=$ methyl $)$ and $\mathrm{Ti}[(c-$ $\left.\left.\left.\mathrm{C}_{5} \mathrm{H}_{9}\right)_{8} \mathrm{Si}_{8} \mathrm{O}_{13}\right)\right]_{2}(2)$, supported on various silicas, and these catalysts showed excellent activities for the epoxidation of cyclooctene by ${ }^{t} \mathrm{BuOOH}$ as an oxidant to selectively give cyclooctene oxide in high yields. On the other hand, catalysts prepared using a corner-capped-type Ti-containing POSS, $\mathrm{CpTi}\left[\left(c-\mathrm{C}_{5} \mathrm{H}_{9}\right)_{7} \mathrm{Si}_{7} \mathrm{O}_{12}\right](3, \mathrm{Cp}=$ cyclopentadienyl), or tetraisopropoxytitanium (4) showed lower activities. The 
catalysts prepared from Ti-bridged POSS can be easily separated from the reaction mixture and reused without a significant loss of activity. These catalysts were also applicable for the epoxidation of limonene. A spectroscopic study revealed that calcination of Ti-bridged POSS supported on silica gave isolated tetrahedral Ti(IV) species, which would be responsible for the high activity, while calcination of silicasupported $\mathbf{3}$ or $\mathbf{4}$ gave aggregated surface titanium oxide species.

KEY WORDS:

Titanium; Silsesquioxane; Silica-supported catalyst; Epoxidation; Cyclooctene;

Limonene 


\section{Introduction}

Siliceous group 4 transition metal catalysts, such as Ti-containing zeolites, are widely used in current chemical industries [1-3]. In particular, titanosilicates such as TS-1 generally show activity that is superior to that of amorphous $\mathrm{TiO}_{2}-\mathrm{SiO}_{2}$ in the epoxidation of small alkenes [3-5]. However, titanium-containing zeolites generally have steric limitations regarding applicable substrates because of their microporous nature. Therefore, the development of novel titanium catalysts with suitable mesoand/or macropores, which contain well-dispersed titanium species, is of great significance.

On the other hand, metal-containing POSS (polyhedral oligomeric silsesquioxanes) have attracted attention as well-defined, homogeneous models of solid siliceous catalysts [6-15]. In particular, the catalytic activities of Ti-containing POSS for the epoxidation of alkenes have been examined [16-23]. In addition to their activities as homogeneous catalysts, their application to heterogeneous catalysis using metal-containing POSS as precursors has been examined [10,13,15,24-31]. The preparation of microporous silicas containing well-dispersed metal oxide species by the controlled calcination of metal-containing POSS has been reported [32-42].

Furthermore, the authors have prepared catalysts possessing both mesopores and 
micropores by the impregnation of metallic salts and POSS ligands onto suitable supports followed by calcination, and these catalysts showed excellent activities for both the aerobic oxidation of benzylic alcohols in water [43] and the hydroformylation of alkenes [44]. In this context, we could expect that it would be easier to prepare silica-supported monomeric Ti(IV) catalysts using Ti-bridged POSS in place of usual Ti-containing precursors such as $\operatorname{Ti}\left(\mathrm{O}^{i} \mathrm{Pr}\right)_{4}[45]$.

We report here the preparation of silica-supported titanium oxide catalysts using Ti-containing POSS as precursors. These oxide catalysts showed excellent activities for the epoxidation of cyclooctene by ${ }^{t} \mathrm{BuOOH}$. The effects of various titanium sources on the activities and physical properties of the thus-prepared oxide catalysts by calcination were examined to identify suitable structures for the required titanium precursors. Changes in the state of Ti-containing POSS during calcination were also investigated. 


\section{Experimental}

Materials and methods. Ti-containing POSS were prepared and subsequent manipulations were performed under an argon atmosphere using standard Schlenk techniques. Dehydrated toluene (Wako) was used as received. Cyclooctene (Nacalai Tesque), limonene (Wako), ${ }^{t} \mathrm{BuOOH}$ in a decane solution (5.5 M, Fluka), tetrakis(dimethylamido)titanium (Gelest), tetraisopropoxytitanium (4; Nacalai Tesque), $\left(c-\mathrm{C}_{5} \mathrm{H}_{9}\right)_{7} \mathrm{Si}_{7} \mathrm{O}_{9}(\mathrm{OH})_{3}$ (Aldrich), and $\left(c-\mathrm{C}_{5} \mathrm{H}_{9}\right)_{8} \mathrm{Si}_{8} \mathrm{O}_{11}(\mathrm{OH})_{2}$ (Aldrich) were obtained commercially and used without further purification. A platinum catalyst (Karsted's catalyst, (divinyltetramethyldisiloxane)platinum(0) (2.1-2.4 wt \%) in xylene) was obtained from Gelest. $\quad\left(c-\mathrm{C}_{5} \mathrm{H}_{9}\right)_{7} \mathrm{Si}_{7} \mathrm{O}_{9}(\mathrm{OH})_{2}\left(\mathrm{OSiMe}_{2} \mathrm{R}\right)(\mathrm{R}=$ vinyl [26], methyl [46]), $\operatorname{Ti}\left[\left(c-\mathrm{C}_{5} \mathrm{H}_{9}\right)_{7} \mathrm{Si}_{7} \mathrm{O}_{11}\left(\mathrm{OSiMe}{ }_{2} \mathrm{R}\right)\right]_{2}(\mathbf{1 a} ; \mathrm{R}=$ vinyl [26], $\mathbf{1 b} ; \mathrm{R}=$ methyl $[18,26])$, and $\mathrm{CpTi}\left[\left(c-\mathrm{C}_{5} \mathrm{H}_{9}\right)_{7} \mathrm{Si}_{7} \mathrm{O}_{12}\right]$ (3) [33] were synthesized based on methods described in previous reports. Dimethylsiloxy-functionalized silica $\left(\mathrm{SiMe}_{2}(\mathrm{H})\right.$-silica, Aldrich) and Cabosil (HS-5, Cabot) were used as received. Mesoporous MCM-41 was prepared based on the method in the literature [47]. JRC silicas were obtained from the Catalysis Society of Japan. The BET surface areas of JRC-SIO-1, -5, -6, -7, and -8 were $104,174,103,88$, and $316 \mathrm{~m}^{2} \mathrm{~g}^{-1}$, respectively. 
Synthesis of Ti[$\left.\left[\left(\boldsymbol{c}-\mathrm{C}_{5} \mathrm{H}_{9}\right)_{8} \mathrm{Si}_{8} \mathrm{O}_{13}\right)\right]_{2}(2)$. To a solution of $\left(c-\mathrm{C}_{5} \mathrm{H}_{9}\right)_{8} \mathrm{Si}_{8} \mathrm{O}_{11}(\mathrm{OH})_{2}(1481$

$\mathrm{mg}, 1.5 \mathrm{mmol})$ in anhydrous toluene $\left(25 \mathrm{~cm}^{3}\right)$, tetrakis(dimethylamido)titanium (168 $\mathrm{mg}$, $0.85 \mathrm{mmol})$ in anhydrous toluene $\left(20 \mathrm{~cm}^{3}\right)$ was dropwise added and the mixture was stirred at room temperature overnight. After the solvent was evaporated, the resulting off-white solid was extracted with hexane $\left(35 \mathrm{~cm}^{3}\right)$. Filtration using a $0.45 \mu \mathrm{m}$ PTFE filter gave a clear solution. After the evaporation of hexane, 2 was obtained by recrystallization by slow diffusion of acetonitrile into a toluene solution. Yield $89 \%$. M.p. $260{ }^{\circ} \mathrm{C}$ (decomp.). ${ }^{1} \mathrm{H}$ NMR $\left(400 \mathrm{MHz}, \mathrm{C}_{6} \mathrm{D}_{6}, 25{ }^{\circ} \mathrm{C}\right) \delta 1.94-1.55$ (128 H, br m), 1.22-1.14 (16 H, br m); ${ }^{13} \mathrm{C}\left\{{ }^{1} \mathrm{H}\right\}$ NMR $\left(75 \mathrm{MHz}, \mathrm{C}_{6} \mathrm{D}_{6}, 25^{\circ} \mathrm{C}\right) \delta 27.81,27.76,27.73$, 27.59, 27.36, 27.35, $27.31\left(\mathrm{CH}_{2}\right.$ of $\left.\mathrm{Cy}\right), 23.39,23.02,22.49$ (1 : $2: 1, \mathrm{CH}$ of $\left.\mathrm{Cy}\right)$; ${ }^{29} \mathrm{Si}\left\{{ }^{1} \mathrm{H}\right\}$ NMR $\left(76 \mathrm{MHz}, \mathrm{C}_{6} \mathrm{D}_{6}, 0.02 \mathrm{M} \mathrm{Cr}(\mathrm{acac})_{3}, 25{ }^{\circ} \mathrm{C}\right) \delta-64.83,-67.65,-68.22(1$ : 2 : 1). Anal. Calcd for $\mathrm{C}_{80} \mathrm{H}_{144} \mathrm{O}_{26} \mathrm{Si}_{16} \mathrm{Ti}$ (2019.22): C, 47.59; H, 7.19. Found C, 47.32; H, 6.93.

Physical and analytical measurements. Solution-phase NMR spectra were recorded on JEOL JNM-EX-400 instruments. $\quad{ }^{1} \mathrm{H}$ and ${ }^{13} \mathrm{C}$ spectra were referenced to internal solvent resonances and reported relative to $\mathrm{SiMe}_{4}$. Chemical shifts for the ${ }^{29} \mathrm{Si}$ nuclei were referenced to an external $\mathrm{SiMe}_{4}$ resonance. Elemental analyses were performed 
at the Microanalytical Center of Kyoto University. The TG-TDA study was performed using a RIGAKU TG8120 system. The sample (ca. $5 \mathrm{mg}$ ) was heated at a rate of 10 ${ }^{\circ} \mathrm{C} \mathrm{min}{ }^{-1}$ under a stream of air $\left(50 \mathrm{~cm}^{3} \mathrm{~min}^{-1}\right)$. Diffuse reflectance infrared Fourier transform (DRIFT) spectra were recorded using a Nicolet Magna-IR 560 FT-IR spectrometer. An uncalcined sample ( $c a .10 \mathrm{wt} \%$, diluted with $\mathrm{KBr}$ powder) was heated in air at an approximate rate of $10{ }^{\circ} \mathrm{C} \mathrm{min}^{-1}$, and the spectrum was recorded after the sample was held at the prescribed temperature for $10 \mathrm{~min}$. X-ray fluorescence (XRF) analysis was performed using a Spectro XEPOS-MS II (25 W).

The oxide catalysts were analyzed by nitrogen gas adsorption, XRD, XPS, and UV-Vis spectroscopy. Nitrogen adsorption/desorption isotherms were obtained with a computer-controlled automatic gas sorption system (Quantachrome NOVA 4200e). Samples were degassed at $573 \mathrm{~K}$ for $30 \mathrm{~min}$ just before the measurements. The mean pore diameter was calculated from the pore volume and the specific surface area assuming that the pore was cylindrical. X-ray powder diffraction patterns were recorded using $\mathrm{Cu} K \alpha$ radiation $(30 \mathrm{kV}, 30 \mathrm{~mA})$ and a carbon monochromator (XRD: XD-D1, Shimadzu). X-ray photoelectron spectra (XPS) of the catalysts were acquired using an ULVAC-PHI 5500MT system equipped with a hemispherical energy analyzer. Samples were mounted on indium foil and then transferred to an XPS analyzer chamber. 
The residual gas pressure in the chamber during data acquisition was less than $1 \times 10^{-8}$

Torr (1 Torr; $133.3 \mathrm{~N} \mathrm{~m}^{-2}$ ). The spectra were measured at room temperature using $\mathrm{Mg}$ $K \alpha$ radiation $(15 \mathrm{kV}, 400 \mathrm{~W})$. The electron take-off angle was set at $45 \mathrm{deg}$. Binding energies were referenced to the $\mathrm{C} 1 \mathrm{~s}$ level of residual graphitic carbon [48]. UVvisible diffuse reflectance spectra were measured with a JASCO V-650 spectrophotometer, in which reflected beams were gathered by an integrating sphere (50 mm inner diameter). A UV cell (10 mm x $40 \mathrm{~mm}$, inner thickness $1.0 \mathrm{~mm})$ equipped with a branched chamber and a stop valve was used to avoid any contact with moisture. The catalyst submitted for measurement was heated in the branched chamber at $473 \mathrm{~K}$ under atmospheric pressure for $30 \mathrm{~min}$, and evacuated at $673 \mathrm{~K}$ followed by treatment under 100 Torr of oxygen at $673 \mathrm{~K}$ for $1 \mathrm{~h}$. The catalyst was then transferred to the UV cell, and spectra were taken in vacuo. Barium sulfate (Nacalai Tesque) was used as a background. All of the spectra were modified in terms of the Kubelka-Munk function. Leaching of titanium species from the catalysts during the reaction was investigated by an ICP atomic emission spectroscopic analysis using a Shimadzu ICPS-1000III analyzer.

Preparation of an oxide catalyst from silica-tethered Ti-POSS. $\mathrm{SiMe}_{2}(\mathrm{H})-$ functionalized silica gel $\left(\mathrm{SiMe}_{2}(\mathrm{H})\right.$-silica, $\left.1.0 \mathrm{~g}\right)$ was treated with a toluene solution $(30$ 
$\mathrm{cm}^{3}$ ) of a Ti-bridged POSS (1a) $(103 \mathrm{mg}, 0.052 \mathrm{mmol})$ in the presence of Karsted's catalyst $\left(0.0022 \mathrm{mmol}, 0.040 \mathrm{~cm}^{3}\right)$ under an Ar atmosphere: The mixture was stirred at $45^{\circ} \mathrm{C}$ for $24 \mathrm{~h}$. Elemental analysis of the support (C 3.83\%, H 1.37\%) indicated the presence of $c a .3 .2 \mathrm{SiMe}_{2}(\mathrm{H})$ groups in a unit surface area of $1 \mathrm{~nm}^{2}$. After filtration, washing of the resulting solid three times with toluene in air and subsequent vacuumdrying gave a tethered catalyst that was designated as $\mathbf{1 a - S i M e}(\mathrm{H})$-silica. There was no sign of $\mathbf{1 a}$ in the filtrate and washing solutions after hydrosilylative condensation, indicating that all of 1a was successfully tethered onto silica. The calcination of 1a$\mathrm{SiMe}_{2}(\mathrm{H})$-silica in air at $550{ }^{\circ} \mathrm{C}$ for $2 \mathrm{~h}$ afforded an oxide catalyst, $1 \mathrm{a}-\mathrm{SiMe}_{2}(\mathrm{H})$-silicacal.

\section{Preparation of oxide catalysts from silica-supported Ti-POSS. A typical} preparation procedure of the silica-supported titanium oxide catalyst using Ti-POSS is as follows: $\mathrm{SiMe}_{2}(\mathrm{H})$-silica $(1.0 \mathrm{~g})$ was impregnated with a toluene solution $\left(3.0 \mathrm{~cm}^{3}\right)$ of $1 \mathrm{a}(98 \mathrm{mg}, 0.050 \mathrm{mmol})$ at $60{ }^{\circ} \mathrm{C}$ in air (however, the impregnation of 4 was performed in an Ar atmosphere to avoid the hydrolysis of $\mathbf{4}$ caused by adventitious contact with moisture). Calcination of the resulting powder (powder derived from $\mathbf{4}$, as well) in air at $550{ }^{\circ} \mathrm{C}$ for $2 \mathrm{~h}$ afforded an oxide catalyst ( $\mathrm{Si} / \mathrm{Ti}$ molar ratio; 350$)$ that was designated 
as 1a@ $\operatorname{SiMe}_{2}(\mathrm{H})$-silica-cal.

Catalytic epoxidation of cyclooctene. All of the reactions were performed with the use of hot stirrers equipped with cooling blocks for refluxing the solvent. Prescribed amounts of the catalyst $(0.50 \mathrm{~mol} \%$ as Ti atom $)$ and cyclooctene $(1.0 \mathrm{mmol})$ in a toluene solution $\left(1.5 \mathrm{~cm}^{3}\right)$ were taken into a $20 \mathrm{~cm}^{3}$ glass Schlenk tube under an Ar atmosphere. This mixture was heated and allowed to equilibrate at $60{ }^{\circ} \mathrm{C}$ for $10 \mathrm{~min} .{ }^{t} \mathrm{BuOOH}(1.0$ mmol) in decane $\left(1.2 \mathrm{~cm}^{3}\right)$ was then added by the use of a plastic pipette. The mixture was stirred for $4 \mathrm{~h}$, and the Schlenk tube was cooled rapidly in an ice bath. The products were identified by the use of GC-MS (Shimadzu GC-MS Parvum 2, Zebron ZB-1 capillary column, i.d. $0.25 \mathrm{~mm}$, length $30 \mathrm{~m}, 50-250{ }^{\circ} \mathrm{C}$ ) and quantified by gas-liquid chromatography (GL Sciences GC353, Inertcap 17 capillary column, i.d. $0.25 \mathrm{~mm}$, length $30 \mathrm{~m}, 50-250{ }^{\circ} \mathrm{C}$ ) using biphenyl as an internal standard.

\section{Results and discussion}

\subsection{Catalytic activity for the epoxidation of cyclooctene}

Silica-supported titanium oxide catalysts were prepared by the calcination $\left(550{ }^{\circ} \mathrm{C}, 2 \mathrm{~h}\right)$ of Ti-containing POSS tethered or supported on various silicas. A silica-tethered catalyst, 
designated as $\mathbf{1 a}-\mathrm{SiMe}_{2}(\mathrm{H})$-silica (see Scheme 1), was prepared by the Pt-catalyzed hydrosilylative condensation of commercially available dimethylsilyl-functionalized silica with vinylsilyl groups of 1a. An oxide catalyst, $\mathbf{1 a - S i M e}(\mathrm{H})$-silica-cal, was prepared by the calcination of $\mathbf{1 a}-\mathrm{SiMe}_{2}(\mathrm{H})$-silica in air at $550{ }^{\circ} \mathrm{C}$ for $2 \mathrm{~h}$. On the other hand, an oxide catalyst designated as $\mathbf{1 a} @ \mathrm{SiMe}_{2}(\mathrm{H})$-silica-cal was prepared by the usual impregnation method from a toluene solution of $\mathbf{1 a}$, followed by calcination.

(Scheme 1)

The activities of these catalysts for the epoxidation of cyclooctene were examined by the use of $t_{\mathrm{BuOOH}}$ as an oxidant (eq. 1). The results are summarized in Table 1. In all of the cases examined, cyclooctene oxide was produced selectively, and the formation of byproducts was negligible. For comparison, the activity of $\mathbf{1 a}$ as a homogeneous catalyst was examined, and this produced cyclooctene oxide in yields of $31 \%$ and $41 \%$ when the reaction was conducted for $1.5 \mathrm{~h}$ and $4 \mathrm{~h}$, respectively (entries 1 and 2). Other Ti-containing POSS, $\mathbf{1 b}$ and $\mathbf{2}$ (see Scheme 2), showed similar activities (entries 3 and 4). The activities of Ti-containing POSS as homogeneous catalysts for the epoxidation by organic peroxides have been previously reported [16-23]. Silica- 
tethered 1a showed a catalytic activity similar to that of 1a, indicating that $1 \mathbf{a}$ was tethered without a loss of activity (entry 5). An oxide catalyst, $\mathbf{1 a}-\mathrm{SiMe}_{2}(\mathrm{H})$-silica-cal, showed a significant activity (70\%; entry 6) than either the homogeneous or tethered Ticontaining POSS catalysts. Furthermore, an oxide catalyst prepared by the usual impregnation method $\left(\mathbf{1 a} @ \mathrm{SiMe}_{2}(\mathrm{H})\right.$-silica-cal) showed slightly higher activity (yield of epoxide; $75 \%$ ) than 1a-SiMe $2(\mathrm{H})$-silica-cal (entry 7), and a high TOF of $71 \mathrm{~h}^{-1}$ was recorded in the reaction for $1.5 \mathrm{~h}$ (entry 8 ). Note that re-examination of the catalytic run shown in entry 7 using the same batch of the catalyst resulted in $78 \%$ yield, and the reaction using another batch of $\mathbf{1 a} @ \mathrm{SiMe}_{2}(\mathrm{H})$-silica-cal afforded the epoxide in $79 \%$ yield. These results indicate good reproducibility of the results in the present system.

(Eq. 1)

(Table 1)

(Scheme 2)

The above results indicate that the tethering of $\mathbf{1 a}$ through covalent bonding did not improve the activity of the resulting catalyst. Therefore, we examined the effects of titanium sources on the activity of the catalysts prepared by the impregnation method. 
As shown in entries 9 and 10, oxide catalysts prepared using $\mathbf{1 b}$ and $\mathbf{2}$ showed higher activities (90\% and $86 \%$ yields, respectively) than that prepared using 1a, while the catalyst prepared using a corner-capped-Ti-containing POSS (3) (see Scheme 2) showed a moderate activity (entry 11), which indicates that Ti-bridged POSSs are excellent titanium precursors. The activity of $\mathbf{4} @ \mathrm{SiMe}_{2}(\mathrm{H})$-silica-cal was poor, even though impregnation was performed under an Ar atmosphere to avoid the hydrolysis of 4 caused by contact with moisture (entry 12). The catalyst prepared by the impregnation of 4 in an air atmosphere gave the epoxide in the lower yield (26\%). On the other hand, Ti-containing POSS can be safely handled in air, which reflects high stability. Except for 1a-SiMe $(\mathrm{H})$-silica, these catalysts did not exhibit activity for epoxidation using an aqueous solution of hydrogen peroxide. Severe non-productive decomposition of hydrogen peroxide was observed in the presence of oxide catalysts such as $\mathbf{1 a}-\mathrm{SiMe}_{2}(\mathrm{H})$-silica-cal and $\mathbf{1 a} @ \mathrm{SiMe}_{2}(\mathrm{H})$-silica-cal. As reported previously, Ti-POSS do not show activity as homogeneous catalysts when hydrogen peroxide is employed as an oxidizing reagent $[23,27]$. In aqueous solutions, Ti-POSS molecules severely aggregate, which would be one reason for the lack of the catalytic activity. On the other hand, Ti-POSS catalysts tethered or immobilized onto polydimethylsiloxane [27], mesoporous silica-polymer composites [28], silyl- 
functionalized silicas [29], and gels composed of POSS molecules [31] were reported to show excellent activities for the epoxidation of alkenes by an aqueous hydrogen peroxide solution. Note that all of these catalysts are heterogeneous and strongly hydrophobic because of the presence of organic groups on their surface. In the present study using oxide catalysts, the active Ti species are present on the hydrophilic surface of the supported oxide catalysts, which would prevent the access of alkenes to the $\mathrm{Ti}$ species, and facilitate non-productive decomposition of hydrogen peroxide.

Table 2 shows the effect of the silica support on the catalytic activity for the epoxidation of cyclooctene. 1a was impregnated onto 7 silica supports [MCM-41, Cabosil, and JRC-SIO-1, -5, -6, -7, and -8], and this was followed by calcination at 550 ${ }^{\circ} \mathrm{C}$. Among the catalysts examined, Cabosil-supported catalysts prepared using Tibridged POSS showed the highest activities (83-88\% yields for $4 \mathrm{~h}$, entries 1,9 , and 10). A high TOF of $91 \mathrm{~h}^{-1}$ was achieved in the reaction for $1.5 \mathrm{~h}$ (entry 2 ). The ICPAES analysis revealed that no titanium species leached into the solution after the reaction using 1a@Cabosil-cal (entry 1).1a@MCM-41-cal also showed excellent activity to afford the desired epoxide in $81 \%$ yield (TOF of $41 \mathrm{~h}^{-1}$ for $4 \mathrm{~h}$, entry 3 ). This activity is comparable to those of MCM-41-based titanium catalysts reported in previous studies $[10,25,30,45]$. For example, a Ti-MCM-41 catalyst (Si/Ti molar 
ratio; 100) showed a TON of $c a .39 \mathrm{~h}^{-1}$ for the epoxidation of cyclooctene by ${ }^{t} \mathrm{BuOOH}$ for $5 \mathrm{~h}$ at $60{ }^{\circ} \mathrm{C}$ (TON; ca. 196 for $5 \mathrm{~h}$ ) [45]. The activities of the catalysts prepared using JRC silicas were moderate. A Cabosil-supported catalyst derived from $\mathbf{3}$ showed a slightly lower TOF in the reaction for $1.5 \mathrm{~h}, 77 \mathrm{~h}^{-1}$ (entry 12), compared to that of the catalyst prepared using 1a (entry 2). Both the Cabosil- and MCM-41-supported catalysts prepared using $\mathbf{4}$ as a titanium source showed lower activities than the catalysts prepared using 1a, 1b, or $\mathbf{2}$ (entries 13-15).

(Table 2)

It is important to determine whether the reaction actually occurs on the solid surface. Hot filtration of the solid catalyst after the reaction in the presence of 1a@Cabosil-cal was allowed to proceed at $60{ }^{\circ} \mathrm{C}$ for $0.5 \mathrm{~h}$ completely suppressed further progress of the reaction (Fig. 1). This result strongly suggests that the catalyst worked heterogeneously.

(Figure 1) 
The epoxidation of a larger alkene, limonene, was performed (eq. 2). The epoxidation selectively occurred at the tri-substituted C-C double bond [30]. As shown in Table 3, the Cabosil-supported catalysts prepared using 1a or $\mathbf{1 b}$ showed slightly higher activity than that of $\mathbf{1 a}$ as a homogeneous catalyst, whereas the catalyst derived from 4 showed the lowest activity. These results suggest the applicability of the supported catalysts for the epoxidation of sterically demanding alkenes.

(Eq. 2)

(Table 3)

One of the major advantages of solid catalysts is the reusability. After the reaction shown in entry 1 of Table 2 , the solid catalyst was separated from the reaction mixture by centrifugation and washed three times with toluene $\left(2.0 \mathrm{~cm}^{3}\right)$. The vacuum-dried catalyst showed slightly lower activity than the fresh catalyst to give the epoxide in $78 \%$ yield. Subsequent calcination at $550{ }^{\circ} \mathrm{C}$ for $2 \mathrm{~h}$ increased the activity of the recovered catalyst and the epoxide was produced in a yield of $81 \%$, indicating that the catalyst was reusable. 


\subsection{Characterization of the oxide catalysts prepared using Ti-POSS}

To examine the effects of Ti-POSS on the properties of the oxide catalysts,

characterization was performed by XRD, nitrogen gas adsorption, UV-Vis spectroscopy, and XPS. The powder XRD patterns of all of the catalysts did not show any peaks due to crystalline titanium oxides, indicating that titanium oxide species were highly dispersed on the surface of the catalysts. The UV-vis spectra reported in Figure 3 (see below) will be more informative on the local environment of Ti species. Table 4 lists the results of nitrogen adsorption measurements of selected catalysts and supports, and Figure 2 shows the nitrogen adsorption/desorption isotherms of $\mathbf{1 a - S i M e}(\mathrm{H})$-silica, $\mathbf{1 a}-$ $\mathrm{SiMe}_{2}(\mathrm{H})$-silica-cal, 1a@ $\mathrm{SiMe}_{2}(\mathrm{H})$-silica-cal, Cabosil, and 1a@Cabosil-cal. All of the catalysts supported on $\mathrm{SiMe}_{2}(\mathrm{H})$-silica showed typical type-IV isotherms [49], indicating the presence of mesopores. The isotherms of Cabosil and 1a@Cabosil-cal were of type-II [49], which indicates the presence of both meso- and macro-pores. In particular, Cabosil possesses a large macropore volume, which would be one reason for the superior activity of Cabosil-supported catalysts, since macropores are advantageous in terms of diffusion of the substrates and the products.

- While the formation of micropores by the calcination of POSS molecules has been previously reported [32-44], an increase in the BET surface area by the calcination of 
silica-supported POSS was not recognized from the results shown in Table 4, probably because of a low loading level of POSS.

(Table 4)

(Figure 2)

UV-Vis spectroscopy is a very powerful tool for investigating the local structure around titanium species in $\mathrm{TiO}_{2}-\mathrm{SiO}_{2}$ mixed oxides [50-52]. The LMCT (ligand-metal charge transfer) transition from $\mathrm{O}$ to $\mathrm{Ti}$ in isolated tetrahedral titanium species is usually observed at a shorter wavelength compared to that of octahedral titanium species. For example, the LMCT transitions of TS-1 and other titanosilicates are observed at $200-220 \mathrm{~nm}$ and are assigned to isolated tetrahedral titanium species [53]. Figure 3 shows the UV-Vis diffuse reflectance spectra of selected catalysts under dehydrated conditions. The oxide catalyst, $1 \mathbf{1 a} @ \operatorname{SiMe}_{2}(\mathrm{H})$-silica-cal, showed a sharp band at $220 \mathrm{~nm}$. 1a-SiMe $(\mathrm{H})$-silica-cal showed a peak that was very similar to that of 1a@ $@ \mathrm{SiMe}_{2}(\mathrm{H})$-silica-cal. These spectra closely resemble those reported for titanosilicates [50,52], and this result clearly indicates that both $\mathbf{1 a - S i M e}(\mathrm{H})$-silica-cal and 1a@ $@ \mathrm{SiMe}_{2}(\mathrm{H})$-silica-cal contain isolated tetrahedral titanium species on their 
surface. The Cabosil- and MCM-41-supported catalysts prepared using 1a also showed absorption at around $220 \mathrm{~nm}$. On the other hand, $3 @ \mathrm{SiMe}_{2}(\mathrm{H})$-silica-cal and $4 @ \mathrm{SiMe}_{2}(\mathrm{H})$-silica-cal both showed a major band at around $260 \mathrm{~nm}$, which has been assigned to octahedral titanium species [51], together with shoulders at $225 \mathrm{~nm}$ and 310 $\mathrm{nm}$. The former shoulder is considered to be due to isolated tetrahedral titanium species, and the latter is due to $\left[\mathrm{TiO}_{2}\right]_{\mathrm{n}}$ clusters [54]. These results suggest the formation of octahedral titanium ions in oxide clusters on the surface of $\mathbf{3} @ \operatorname{SiMe}_{2}(\mathrm{H})$-silica-cal and $4 @ \mathrm{SiMe}_{2}(\mathrm{H})$-silica-cal. The spectrum of $4 @$ Cabosil-cal showed very similar to those of $\mathbf{3} @ \mathrm{SiMe}_{2}(\mathrm{H})$-silica-cal and 4@ $\mathrm{SiMe}_{2}(\mathrm{H})$-silica-cal.

(Figure 3)

The XPS study revealed the presence of Ti(IV) species on the surface of all of the catalysts examined. Figure 4 shows selected results. Remarkably, 1a@ $@ \mathrm{SiMe}_{2}(\mathrm{H})-$ silica-cal showed a Ti $2 \mathrm{p}_{3 / 2}$ band at $460.0 \mathrm{eV}$, which is significantly higher than those of $3 @ \mathrm{SiMe}_{2}(\mathrm{H})$-silica-cal and 4@ $\mathrm{SiMe}_{2}(\mathrm{H})$-silica-cal $(458.5 \mathrm{eV}) . \quad$ Since Ti $2 \mathrm{p}_{3 / 2}$ peaks centered at ca. $460 \mathrm{eV}$ and $458-459 \mathrm{eV}$ have been assigned to a framework tetrahedral titanium and an extraframework octahedral titanium phase for titanosilicates, 
respectively $[53,55,56]$, the present result is consistent with the formation of tetrahedral titanium species on the surface of $\mathbf{1 a} @ \mathrm{SiMe}_{2}(\mathrm{H})$-silica-cal.

(Figure 4)

Changes in the structures of Ti- POSS during calcination were investigated by TG-DTA, DRIFT, and NMR measurements. Since several POSS have been reported to be volatile in spite of their relatively large molecular weights $[6,7,9]$, the loss of Ti and Si species during the calcination of Ti-POSS was examined by treating $\mathbf{1 a}, \mathbf{1 b}, \mathbf{2}$, and $\mathbf{3}$ in air at $550{ }^{\circ} \mathrm{C}$ for $2 \mathrm{~h}$ in the box furnace. The ceramic yields of $\mathrm{SiO}_{2}-\mathrm{TiO}_{2}$ from $\mathbf{1 a}$ (49.6\%) and $\mathbf{1 b}(49.4 \%)$ were slightly lower than the theoretical values $(53.0 \%$ and $53.8 \%$ for $\mathbf{1 a}$ and $\mathbf{1 b}$, respectively). The XRF analyses showed that $\mathrm{Si} / \mathrm{Ti}$ atomic ratios of the resulting oxides from $\mathbf{1 a}$ and $\mathbf{1 b}$ were $14.8( \pm 0.2)$ and $14.9( \pm 0.1)$, respectively. These results indicate that by the calcination of both Ti-POSS, 7( \pm 1$) \%$ of Si was lost, while $100( \pm 2) \%$ and $99( \pm 1) \%$ of Ti was remaining in the resulting oxides from $1 \mathbf{a}$ and $\mathbf{1 b}$, respectively. During the calcination of $\mathbf{1 a}$ and $\mathbf{1 b}$, trimethylsilyl or dimethylvinylsilyl groups in $\mathbf{1 a}$ or $\mathbf{1 b}$ would be cleft at relatively low temperature and then sublime, as revealed by the TG study (see below). On the other hand, the ceramic 
yields of oxides from $\mathbf{2}(52.5 \%)$ and $\mathbf{3}(51.0 \%)$ were very close to the theoretical values (51.6\% and 50.8\%, respectively). These results indicate the absence of loss of Ti species during the calcination of POSS at $550{ }^{\circ} \mathrm{C}$ for $2 \mathrm{~h}$.

As shown in Figure 5, the TG-DTA study demonstrated the stepwise decomposition of $\mathbf{1 a}$ and $\mathbf{3}$ in an air stream. Note that TG-DTA measurements of supported Ti-POSS did not give any distinct TG and DTA responses, probably because of the low loading levels. For 1a, decreases in weight by $7 \%$ and $42 \%$ were observed at $300-350{ }^{\circ} \mathrm{C}$ and $400-600{ }^{\circ} \mathrm{C}$, respectively. A slightly exothermic decrease at 300 $350{ }^{\circ} \mathrm{C}$ would be due to the oxidative cleavage of dimethylvinylsilyl groups, and a significant loss of weight above $400{ }^{\circ} \mathrm{C}$ is due to the combustion of cyclopentyl groups. The decomposition of $\mathbf{3}$ also proceeded in a stepwise manner: an initial endothermic loss of weight by $6 \%$ at $c a .315^{\circ} \mathrm{C}$ and a significantly exothermic loss above $320{ }^{\circ} \mathrm{C}$.

(Figure 5)

The DRIFT spectra of $\mathbf{1 a}$ and $\mathbf{3}$ treated in air at various temperatures are shown in Figure 6. While the spectrum of uncalcined 1a showed strong C-H stretching vibrations due to cyclopentyl groups at $2950 \mathrm{~cm}^{-1}$ and $2870 \mathrm{~cm}^{-1}$, these bands almost 
disappeared above $350{ }^{\circ} \mathrm{C}$. This result is consistent with that of the TG-DTA study, which indicates the combustion of organic substituents in this temperature range. In the spectrum of $\mathbf{3}$, a C-H out-of-plane bending vibration band characteristic of a $\mathrm{Cp}$ group is observed at about $806 \mathrm{~cm}^{-1}$. This peak disappeared when the sample was heated to $300{ }^{\circ} \mathrm{C}$. This result supports the argument on the TG study, which indicated the decomposition of the $\mathrm{Cp}$ group of $\mathbf{3}$ at this temperature range. Again, $\mathrm{C}-\mathrm{H}$ stretching vibrations of aliphatic $\mathrm{C}-\mathrm{H}$ bonds disappeared above $350{ }^{\circ} \mathrm{C}$ because of the complete combustion of organic groups. Note that a broad, strong band at about 940 $\mathrm{cm}^{-1}$ is observed for the spectra of both $\mathbf{1 a}$ and $\mathbf{3}$ above $350{ }^{\circ} \mathrm{C}$, which is often reported to be a good fingerprint of the existence of framework titanium species in titanosilicates $[51,57,58]$

(Figure 6)

Loss of the Cp group from 3 at around $300{ }^{\circ} \mathrm{C}$ was also confirmed by ${ }^{1} \mathrm{H}$ and ${ }^{13} \mathrm{C}$ NMR studies. The treatment of 3 at $300{ }^{\circ} \mathrm{C}$ for 10 min (heating rate $10{ }^{\circ} \mathrm{C} \mathrm{min}^{-1}$ ) in an air stream gave a slightly brownish powder, which was soluble in $\mathrm{CDCl}_{3}$ except for a trace amount of brown solid. In the ${ }^{1} \mathrm{H}$ NMR spectrum, the peak of a $\mathrm{Cp}$ ring (6.43 
ppm) completely disappeared, while resonances attributed to cyclopentyl groups

remained. The ${ }^{13} \mathrm{C}$ NMR spectrum did not show the peak assignable to the $\mathrm{Cp}$ ring of

3.

As shown in the first part of the present study, the oxide catalysts prepared

using $\mathbf{1 a}, \mathbf{1 b}$, and $\mathbf{2}$ as titanium sources showed activities superior to those prepared

from 3 and 4. The combined results of characterization clearly indicate the selective

formation of isolated tetrahedral titanium(IV) species on the surface of the oxide

catalysts from $\mathbf{1 a}, \mathbf{1 b}$, and $\mathbf{2}$, and such titanium species would be responsible for the

high catalytic activity. Therefore, Ti-bridged POSS are expected to act as precursors

of "titanosilicate-like" species. One common feature of $\mathbf{1 a}, \mathbf{1} \mathbf{b}$, and $\mathbf{2}$ is that the

titanium atom is surrounded by bulky POSS cages through four Ti-O-Si bonds.

During calcination, these POSS moieties would be transformed into small silica clusters,

which might act as an inorganic separator of titanium species $[43,44]$. This would

prevent the aggregation of titanium oxide species and thus promote the formation of

isolated titanium(IV) species on the silica surface. Note that the TG-DTA study of $\mathbf{3}$

revealed that the $\mathrm{Cp}$ (cyclopentadienyl) group decomposed at around $315^{\circ} \mathrm{C}$, which is a

lower temperature than that for the combustion of cyclopentyl groups $\left(\mathrm{ca} .400{ }^{\circ} \mathrm{C}\right)$. The

loss of the Cp group from 3 in the present study might enable the aggregation of $\mathrm{Ti}$ 
species.

\section{Conclusion}

Silica-supported titanium oxide catalysts with excellent activities for the epoxidation of cyclooctene by ${ }^{t} \mathrm{BuOOH}$ were prepared by the calcination of Ti-bridged POSS supported or tethered on silica at $550{ }^{\circ} \mathrm{C}$. Based on the results of catalytic runs and spectroscopic analyses of the catalysts, highly isolated tetrahedral titanium(IV) species were revealed to be produced on the catalyst surface from 1a, $\mathbf{1 b}$, or $\mathbf{2}$, while aggregated titanium species were produced from a corner-capped-type Ti-POSS (3) and tetraisopropoxytitanium (4). These catalysts were also applicable for the epoxidation of limonene. The present study clearly indicates the utility of Ti-bridged POSS as promising precursors for titanosilicate-like active titanium species, which can be implanted on a variety of oxide supports. The present results suggest that compounds that include a titanium atom surrounded by bulky inorganic moieties through four Ti-OSi bonds may be suitable precursors for epoxidation catalysts. Further attempts to improve the catalytic activities of these catalysts and the application to the epoxidation of much bulky alkenes, as well as the development of much more efficient titanium precursors, are underway. 


\section{Acknowledgement}

This work was supported in part by a Grant-in Aid for Scientific Research (No.

18360388) from the Ministry of Education, Sports, Culture, Science, and Technology,

Japan. K. W. acknowledges financial support from the Okura Foundation.

\section{References}

[1] K. Weissermel, H.J. Arpe, Industrial Organic Chemistry, 3rd ed, VCH, Weinheim (1997)

[2] I.W.C.E. Arends, R.A. Sheldon, M. Wallau, U. Schuchardt, Angew. Chem. Int. Ed. 36 (1997) 1144, and references therein.

[3] B. Notari, Adv. Catal. 41 (1996) 253.

[4] S. Bordiga, A. Damin, F. Bonino, G. Ricchiardi, C. Lamberti, A. Zecchina, Angew. Chem. Int. Ed. 41 (2002) 4734.

[5] S. Bordiga, F. Bonino, A. Damin, C. Lamberti, Phys. Chem. Chem. Phys. 9 (2007) 4854.

[6] For a review, see: R.H. Baney, M. Itoh, A. Sakakibara, T. Suzuki, Chem. Rev. 95 (1995) 1409. 
[7] F.J. Feher, T.A. Budzichowski, Polyhedron 14 (1995) 3239.

[8] R. Murugavel, A. Voigt, M.G. Walawalker, H.W. Roesky, Chem. Rev. 96 (1996) 2205.

[9] P.G. Harrison, J. Organomet. Chem. 542 (1997) 141.

[10] H.C.L. Abbenhuis, Chem. Eur. J. 6 (2000) 25.

[11] V. Lorenz, A. Fischer, S. Giessmann, J.W. Gilje, Y. Gun'ko, K. Jacob, F.T.

Edelmann, Coord. Chem. Rev. 206-207 (2000) 321.

[12] R. Duchateau, Chem. Rev. 102 (2002) 3525.

[13] C. Copéret, M. Chabanas, R.P. Saint-Arroman, J.M. Basset, Angew. Chem. Int. Ed. $42(2003) 156$.

[14] R.W.J.M. Hanssen, R.A. van Santen, H.C.L. Abbenhuis, Eur. J. Inorg. Chem. (2004) 675 .

[15] K. Wada, T. Mitsudo, Catal. Survey Asia 9 (2005) 229.

[16] H.C.L. Abbenhuis, S. Krijnen, R.A. van Santen, Chem. Commun. (1997) 331.

[17] T. Maschmeyer, M.C. Klunduk, C.M. Martin, D.S. Shephard, J.M. Thomas, B.F.G. Johnson, Chem. Commun. (1997) 1847.

[18] M. Crocker, R.H.M. Herold, A.G. Orpen, Chem. Commun. (1997) 2411.

[19] J.M. Thomas, G. Sankar, M.C. Klunduk, M.P. Attfield, T. Maschmeyer, B.F.G. 
Johnson, R.G. Bell, J. Phys. Chem. B 103 (1999) 8809.

[20] M. Crocker, R.H.M. Herold, A.G. Orpen, M.T.A. Overgaag, J. Chem. Soc., Dalton Trans. (1999) 3791.

[21] B.F.G. Johnson, M.C. Klunduk, C.M. Martin, G. Sankar, S.J. Teate, J.M. Thomas, J. Organomet. Chem. 596 (2000) 221.

[22] P.P. Pescarmona, J.C. van der Waal, I.E. Maxwell, T. Maschmeyer, Angew. Chem. Int. Ed. 40 (2001) 740.

[23] K. Wada, N. Itayama, N. Watanabe, M. Bundo, T. Kondo, T. Mitsudo, Organometallics 23 (2004) 5824.

[24] H.C.L. Abbenhuis, H.W.G. van Herwijnen, R.A. van Santen, Chem. Commun. (1996) 1941.

[25] S. Krijnen, H.C.L. Abbenhuis, R.W.J.M. Hanssen, J.H.C. van Hooff, R.A. van Santen, Angew. Chem. Int. Ed. 37 (1998) 356.

[26] K. Wada, K. Yamada, D. Izuhara, T. Kondo, T. Mitsudo, Chem. Lett. (2000) 1332.

[27] M.D. Skowronska-Ptasinska, M.L.W.Vorstenbosch, R.A. van Santen, H.C.L. Abbenhuis, Angew. Chem. Int. Ed. 41 (2002) 637.

[28] L. Zhang, H.C.L. Abbenhuis, G. Gerritsen, N.N. Bhriain, P.C.M.M. Magusin, B. Mezari, W. Han, R.A. van Santen, Q. Yang, C. Li, Chem. Eur. J. 13 (2007) 1210. 
[29] K. Wada, N. Watanabe, T. Kondo, T. Mitsudo, Chem. Eng. Sci. 63 (2008) 4917.

[30] F. Carniato, C. Bisio, E. Boccaleri, M. Guidotti, E. Gavrilova, L. Marchese, Chem. Eur. J. 14 (2008) 8098.

[31] K. Wada, K. Hirabayashi, N. Watanabe, S. Yamamoto, T. Kondo, T. Mitsudo, M. Inoue, Top. Catal. 52 (2009) 693.

[32] K. Wada, M. Nakashita, A. Yamamoto, T. Mitsudo, Chem. Commun. (1998) 133.

[33] K. Wada, M. Nakashita, M. Bundo, K. Ito, T. Kondo, T. Mitsudo, Chem. Lett. (1998) 659.

[34] K. Wada, K. Yamada, T. Kondo, T. Mitsudo, Chem. Lett. (2001) 12.

[35] K. Wada, K. Yamada, T. Kondo, T. Mitsudo, J. Jpn. Petrol. Inst. 45 (2002) 15.

[36] K. Wada, K. Tada, N. Itayama, T. Kondo, T. Mitsudo, J. Catal. 228 (2004) 374.

[37] N. Maxim, H.C.L. Abbenhuis, P.J. Stobbelaar, B.L. Mojet, R.A. van Santen, Phys. Chem. Chem. Phys. 1 (1999) 4473.

[38] N. Maxim, H.C.L. Abbenhuis, P.C.M.M. Magusin, R.A. van Santen, Chinese J. Chem. 19 (2001) 30.

[39] N. Maxim, P.C.M.M. Magusin, P.J. Kooyman, J.H.M.C. van Wolput, R.A. van Santen, H.C.L. Abbenhuis, Chem. Mater. 13 (2001) 2958.

[40] N. Maxim, A. Overweg, P.J. Kooyman, A. Nagy, R.A. van Santen, H.C.L. 
Abbenhuis, J. Mater. Chem. 12 (2002) 3792.

[41] N. Maxim, A. Overweg, P.J. Kooyman, J.H.M.C. van Wolput, R.W.J.M. Hanssen, R.A. van Santen, H.C.L. Abbenhuis, J. Phys. Chem. B 106 (2002) 2203.

[42] R. Murugavel, P. Davis, V.S. Shete, Inorg. Chem. 42 (2003) 4696.

[43] K. Wada, K. Yano, T. Kondo, T. Mitsudo, Catal. Today 117 (2006) 242.

[44] K. Wada, R. Tomoyose, T. Kondo, T. Mitsudo, Appl. Catal. A: Gen. 356 (2009) 72.

[45] C. Galacho, M.M.L. Ribeiro Carrott , P.J.M. Carrott, Microporous Mesoporous Mater. 100 (2007) 312, and references therein.

[46] H.C.L. Abbenhuis, A.D. Burrows, H. Kooijman, M. Lutz, M.T. Palmer, R.A. van Santen, A.L. Spek, Chem. Commun. (1998) 2627.

[47] Q. Cai, W.-Y. Lin, F.-S. Xiao, W.-Q. Pang, X.-H. Chen, B.-S. Zou, Microporous Mesoporous Mater. 32 (1999) 1.

[48] F. Moulder, W.F. Stickle, P.E. Sobol, K.D. Bomben, Handbook of X-ray Photoelectron Spectroscopy, Perkin-Elmer Co., Eden Prairie (USA), 1992.

[49] S.J. Greg, K.S.W. Sing, Adsorption, Surface Area and Porosity, 2nd ed. Academic Press, London (UK), 1982.

[50] X. Gao, I.E. Wachs, Catal. Today 51 (1999) 233, and references therein.

[51] C. Murata, H. Yoshida, T. Hattori, Stud. Surf. Sci. Catal. 143 (2002) 845. 
[52] S. Bordiga, S. Coluccia, C. Lamberti, L. Marchese, A. Zecchina, F. Boscherini, F. Buffa, F. Genoni, G. Leofanti, G. Petrini, G. Vlaic, J. Phys. Chem. 98 (1994) 4125.

[53] T. Blasco, M.A. Camblor, J.L.G. Fierro, J. Pérez-Pariente, Microporous Mater. 3 (1994) 259.

[54] C. Kormann, D.W. Bahnemann, M.R. Hoffmann, J. Phys. Chem. 92 (1988) 5196.

[55] I. Grohmann, W. Pilz, G. Walther, H. Kosslick, V.A. Tuan, Surf. Interface Anal. 22 (1994) 403.

[56] L. LeNoc, D.T. On, S. Solomykina, B. Echchahed, F. Beland, C.C.D. Moulin, L. Bonneviot, Stud. Surf. Sci. Catal. 101 (1996) 611.

[57] G. Perego, G. Bellussi, C. Corno, M. Taramasso, F. Buonomo, A. Esposito, Stud. Surf. Sci. Catal. 28 (1986) 129.

[58] G. Ricchiardi, A. Damin, S. Bordiga, C. Lamberti, G. Spanó, F. Rivetti, A. Zecchina, J. Am. Chem. Soc. 123 (2001) 11409. 


\section{Captions for Schemes and Figures}

Scheme 1. Preparation of a silica-tethered catalyst and an oxide catalyst.

Scheme 2. Ti-containing POSS used for the preparation of oxide catalysts.

Figure 1. Time course of the epoxidation of cyclooctene in the presence of 1a@Cabosil-cal (a) without and (b) with hot filtration of the catalyst $0.5 \mathrm{~h}$ after the reaction started.

Figure 2. Nitrogen adsorption / desorption isotherms of (a) $\mathbf{1 a - S i M e}(\mathrm{H})$-silica, (b) 1a$\mathrm{SiMe}_{2}(\mathrm{H})$-silica-cal, (c) 1a@ $@ \mathrm{SiMe}_{2}(\mathrm{H})$-silica-cal, (d) Cabosil, and (e) 1a@Cabosil-cal. Filled and open symbols show adsorption and desorption data, respectively.

Figure 3. UV-Vis diffuse reflectance spectra of (a) 1a@ $\mathrm{SiMe}_{2}(\mathrm{H})$-silica-cal, (b)

$3 @ \mathrm{SiMe}_{2}(\mathrm{H})$-silica-cal, (c) $4 @ \mathrm{SiMe}_{2}(\mathrm{H})$-silica-cal, (d) 1a-SiMe $2(\mathrm{H})$-silica-cal, (e) 1a@Cabosil-cal, (f) 4@Cabosil-cal, and (g) 1a@MCM-41-cal. 
Figure 4. Ti 2p spectra of (a) $1 \mathrm{a} @ \mathrm{SiMe}_{2}(\mathrm{H})$-silica, (b) $3 @ \mathrm{SiMe}_{2}(\mathrm{H})$-silica-cal, and (c) 4@ $\mathrm{SiMe}_{2}(\mathrm{H})$-silica-cal.

Figure 5. TG-DTA profiles of (a) 1a and (b) 3 in a stream of air.

Figure 6. DRIFT spectra of (a) 1a and (b) 3 recorded in air at elevated temperatures.

Samples were diluted by $\mathrm{KBr}$ to be $c a .10 \mathrm{wt} \%$, and spectra in the region exceeding 3

Kubelka-Munk units are omitted. 


\section{TEXT FOR GRAPHICAL ABSTRACT}

The controlled calcination of Ti-bridged polyhedral oligomeric silsesquioxanes (POSS)

supported on silicas afforded the oxide catalysts with isolated tetrahedral Ti(IV) species

on the surface, which showed excellent catalytic activities for the epoxidation of

cyclooctene by ${ }^{t} \mathrm{BuOOH}$. 


\section{Tables}

Table 1. Catalytic activity of Ti-containing POSS-based catalyst for the epoxidation of cyclooctene by ${ }^{t} \mathrm{BuOOH}^{a}$

\begin{tabular}{cllll}
\hline Entry & \multicolumn{1}{c}{ Catalyst } & $\begin{array}{c}\text { Reaction } \\
\text { Time }(\mathrm{h})\end{array}$ & $\begin{array}{c}\text { Epoxide } \\
\text { yield }(\%)^{b}\end{array}$ & $\begin{array}{c}\text { TOF } \\
\left(\mathrm{h}^{-1}\right)\end{array}$ \\
\hline 1 & 1a (homogeneous) & 4 & 41 & 21 \\
2 & 1a (homogeneous) & 1.5 & 31 & 41 \\
3 & 1b (homogeneous) & 1.5 & 33 & 44 \\
4 & $\mathbf{2}$ (homogeneous) & 1.5 & 29 & 39 \\
5 & 1a-SiMe $2(\mathrm{H})$-silica & 4 & 41 & 21 \\
6 & $\mathbf{1 a}-\mathrm{SiMe}_{2}(\mathrm{H})$-silica-cal & 4 & 70 & 35 \\
7 & $\mathbf{1 a} @ \mathrm{SiMe}_{2}(\mathrm{H})$-silica-cal & 4 & 75 & 38 \\
8 & $\mathbf{1 a} @ \mathrm{SiMe}_{2}(\mathrm{H})$-silica-cal & 1.5 & 53 & 71 \\
9 & $\mathbf{1 b} @ \mathrm{SiMe}_{2}(\mathrm{H})$-silica-cal & 4 & 90 & 45 \\
10 & $\mathbf{2} @ \mathrm{SiMe}_{2}(\mathrm{H})$-silica-cal & 4 & 86 & 43 \\
11 & $\mathbf{3} @ \mathrm{SiMe}_{2}(\mathrm{H})$-silica-cal & 4 & 60 & 30 \\
12 & $\mathbf{4} @ \mathrm{SiMe}_{2}(\mathrm{H})$-silica-cal & 4 & 39 & 20 \\
\hline
\end{tabular}

${ }^{a}$ The reaction conditions are shown in eq. $1 .{ }^{b}$ Yield based on cyclooctene determined by GLC. 
Table 2. Effect of silica support and Ti precursors for the epoxidation of cyclooctene by ${ }^{t} \mathrm{BuOOH}^{a}$

\begin{tabular}{clccl}
\hline Entry & \multicolumn{1}{c}{ Catalyst } & $\begin{array}{c}\text { Reaction } \\
\text { Time }(\mathrm{h})\end{array}$ & $\begin{array}{c}\text { Epoxide } \\
\text { yield }(\%)^{b}\end{array}$ & $\begin{array}{c}\text { TOF } \\
\left(\mathrm{h}^{-1}\right)\end{array}$ \\
\hline 1 & 1a@Cabosil-cal & 4 & 88 & 44 \\
2 & 1a@Cabosil-cal & 1.5 & 68 & 91 \\
3 & 1a@MCM-41-cal & 4 & 81 & 41 \\
4 & 1a@JRC-SIO-1-cal & 4 & 68 & 34 \\
5 & 1a@JRC-SIO-5-cal & 4 & 77 & 39 \\
6 & 1a@JRC-SIO-6-cal & 4 & 71 & 36 \\
7 & 1a@JRC-SIO-7-cal & 4 & 66 & 33 \\
8 & 1a@JRC-SIO-8-cal & 4 & 75 & 38 \\
9 & 1b@Cabosil-cal & 4 & 87 & 44 \\
10 & 2@Cabosil-cal & 4 & 83 & 42 \\
11 & 3@Cabosil-cal & 4 & 87 & 44 \\
12 & 3@Cabosil-cal & 1.5 & 58 & 77 \\
13 & 4@Cabosil-cal & 4 & 72 & 36 \\
14 & 4@Cabosil-cal & 1.5 & 46 & 61 \\
15 & 4@MCM-41-cal & 4 & 53 & 27 \\
\hline
\end{tabular}

${ }^{a}$ The reaction conditions are shown in eq. $1 .{ }^{b}$ Yield based on cyclooctene determined by GLC. 
Table 3. Effect of silica-supports on Ti catalysts for the epoxidation of limonene by ${ }^{t} \mathrm{BuOOH}^{a}$

\begin{tabular}{clcc}
\hline Entry & \multicolumn{1}{c}{ Catalyst } & $\begin{array}{c}\text { Epoxide } \\
\text { yield }(\%)^{b}\end{array}$ & $\begin{array}{c}\text { TOF } \\
\left(\mathrm{h}^{-1}\right)\end{array}$ \\
\hline 1 & 1a (homogeneous) & 23 & 12 \\
2 & 1a@Cabosil-cal & 27 & 14 \\
3 & 1b@Cabosil-cal & 24 & 12 \\
4 & 2@Cabosil-cal & 22 & 11 \\
5 & 4@Cabosil-cal & 15 & 8 \\
\hline${ }^{a}$ The reaction conditions are shown in eq. $2 .^{b}$ Yield based on \\
cyclooctene determined by GLC.
\end{tabular}


Table 4. Summary of the results of nitrogen adsorption measurements of the selected catalysts and supports

\begin{tabular}{|c|c|c|c|}
\hline Catalyst & $\begin{array}{l}\text { BET S. A. } \\
\left(\mathrm{m}^{2} \mathrm{~g}^{-1}\right)\end{array}$ & 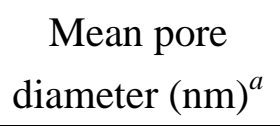 & $\begin{array}{c}\text { Total pore } \\
\text { volume }\left(\mathrm{cm}^{3} \mathrm{~g}^{-1}\right)\end{array}$ \\
\hline $\mathrm{SiMe}_{2}(\mathrm{H})$-silica & 394 & 6.0 & 0.55 \\
\hline $\mathrm{SiMe}_{2}(\mathrm{H})$-silica-cal & 420 & 5.9 & 0.62 \\
\hline $\mathbf{1 a}-\mathrm{SiMe}_{2}(\mathrm{H})$-silica & 410 & 5.4 & 0.55 \\
\hline $\mathbf{1 a}-\mathrm{SiMe}_{2}(\mathrm{H})$-silica-cal & 444 & 5.9 & 0.66 \\
\hline 1a@ $@ \operatorname{SiMe}_{2}(\mathrm{H})$-silica-cal & 394 & 5.6 & 0.55 \\
\hline 1b@ $@ \operatorname{SiMe}_{2}(\mathrm{H})$-silica-cal & 399 & 5.7 & 0.57 \\
\hline $2 @ \operatorname{SiMe}_{2}(\mathrm{H})$-silica-cal & 396 & 5.6 & 0.55 \\
\hline $3 @ \operatorname{SiMe}_{2}(\mathrm{H})$-silica-cal & 413 & 5.8 & 0.60 \\
\hline $4 @ \operatorname{SiMe}_{2}(\mathrm{H})$-silica-cal & 409 & 5.8 & 0.59 \\
\hline Cabosil & 320 & 10.8 & 0.86 \\
\hline 1a@Cabosil-cal & 276 & 9.4 & 0.65 \\
\hline 4@Cabosil-cal & 303 & 9.3 & 0.71 \\
\hline MCM-41 & 1396 & 2.6 & 0.90 \\
\hline 1a@MCM-41-cal & 1405 & 2.4 & 0.83 \\
\hline
\end{tabular}

${ }^{a}$ The mean pore diameter was calculated from the pore volume and the specific surface area assuming that the pore was cylindrical. 


\section{A Self-archived copy in}

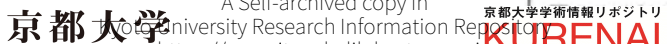

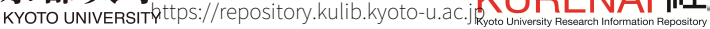

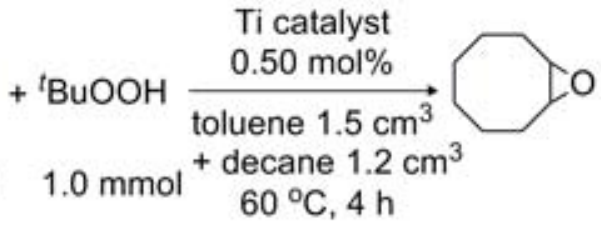




\section{A Self-archived copy in}

产教

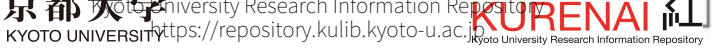

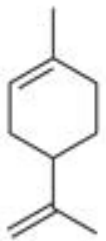

$+{ }^{t} \mathrm{BuOOH}$

Ti catalyst

$0.50 \mathrm{~mol} \%$

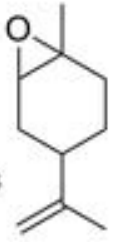

toluene $1.5 \mathrm{~cm}^{3}$

+ decane $1.2 \mathrm{~cm}^{3}$ $60^{\circ} \mathrm{C}, 4 \mathrm{~h}$ 


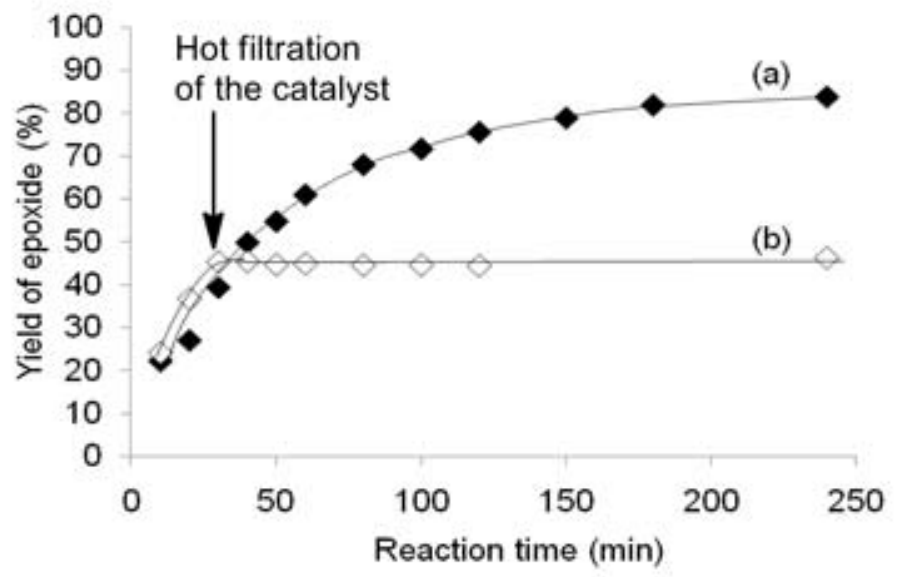


A Self-archived copy in
京都大
KYOTO UNIVERITY
https://repositorch.kulib.kyoto-u.ac.jp
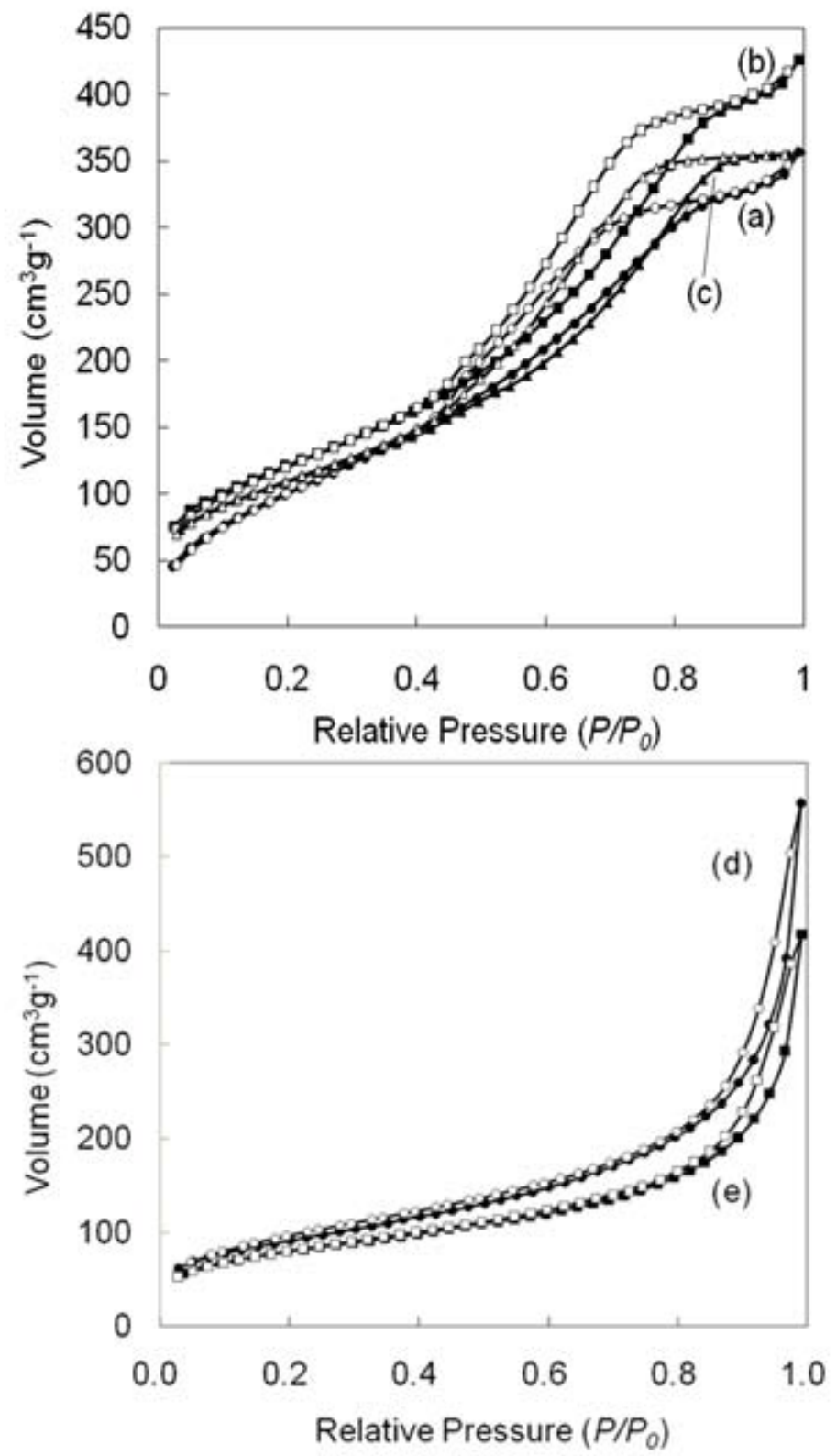
Figure 3
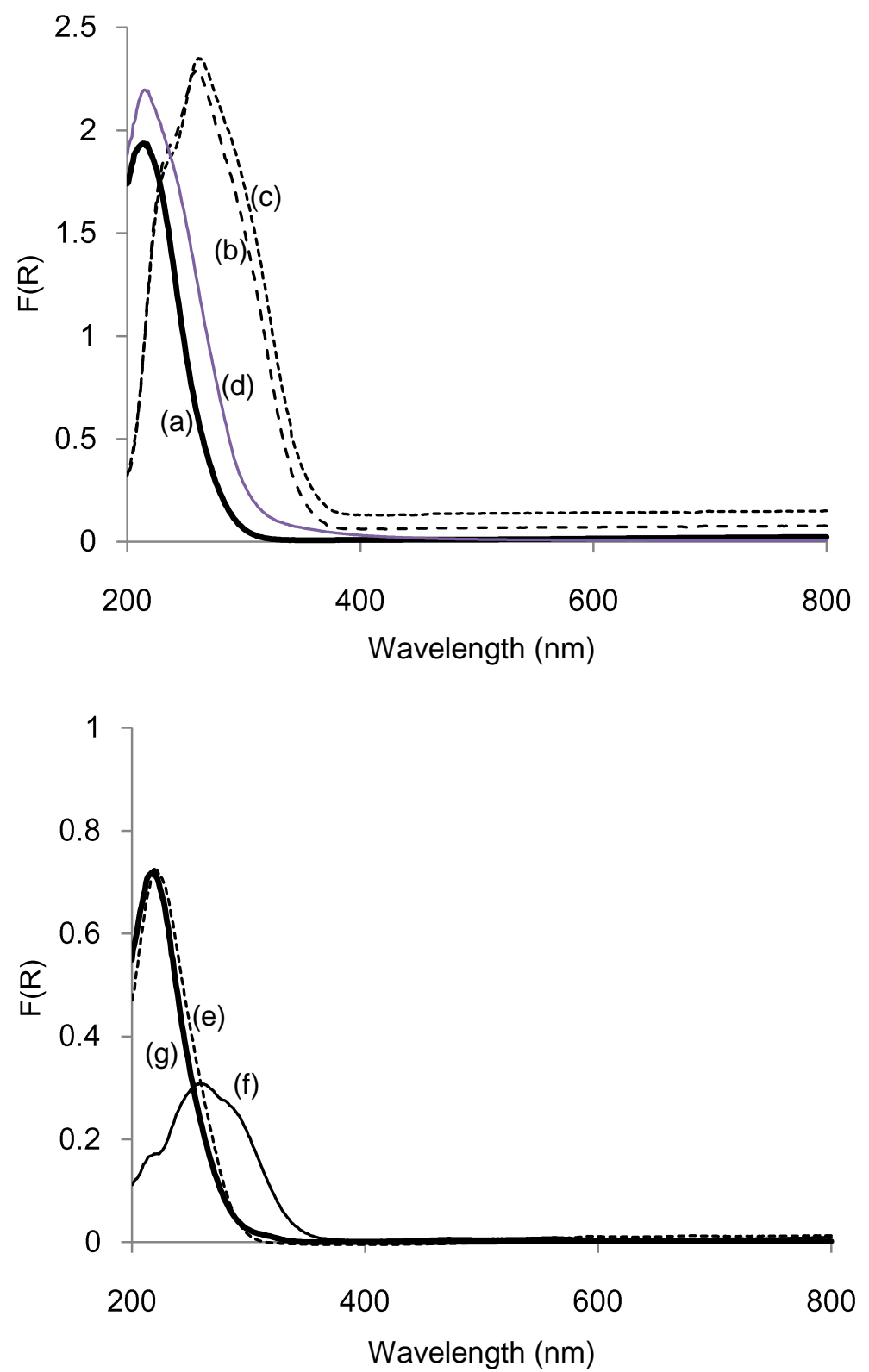
Figure 4

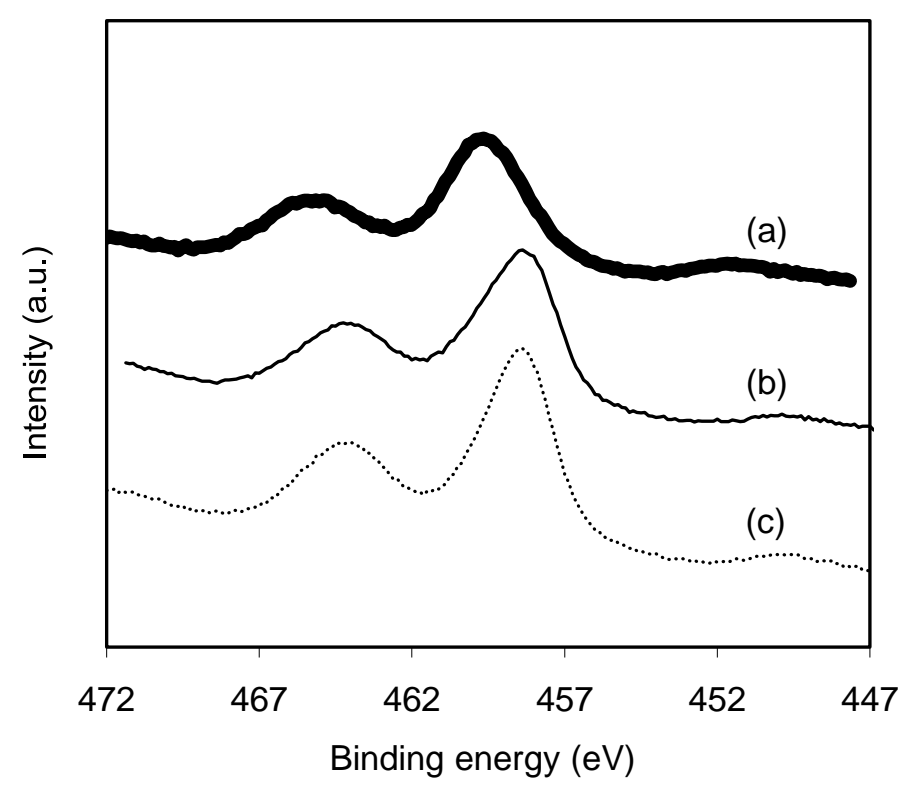


Figure 6
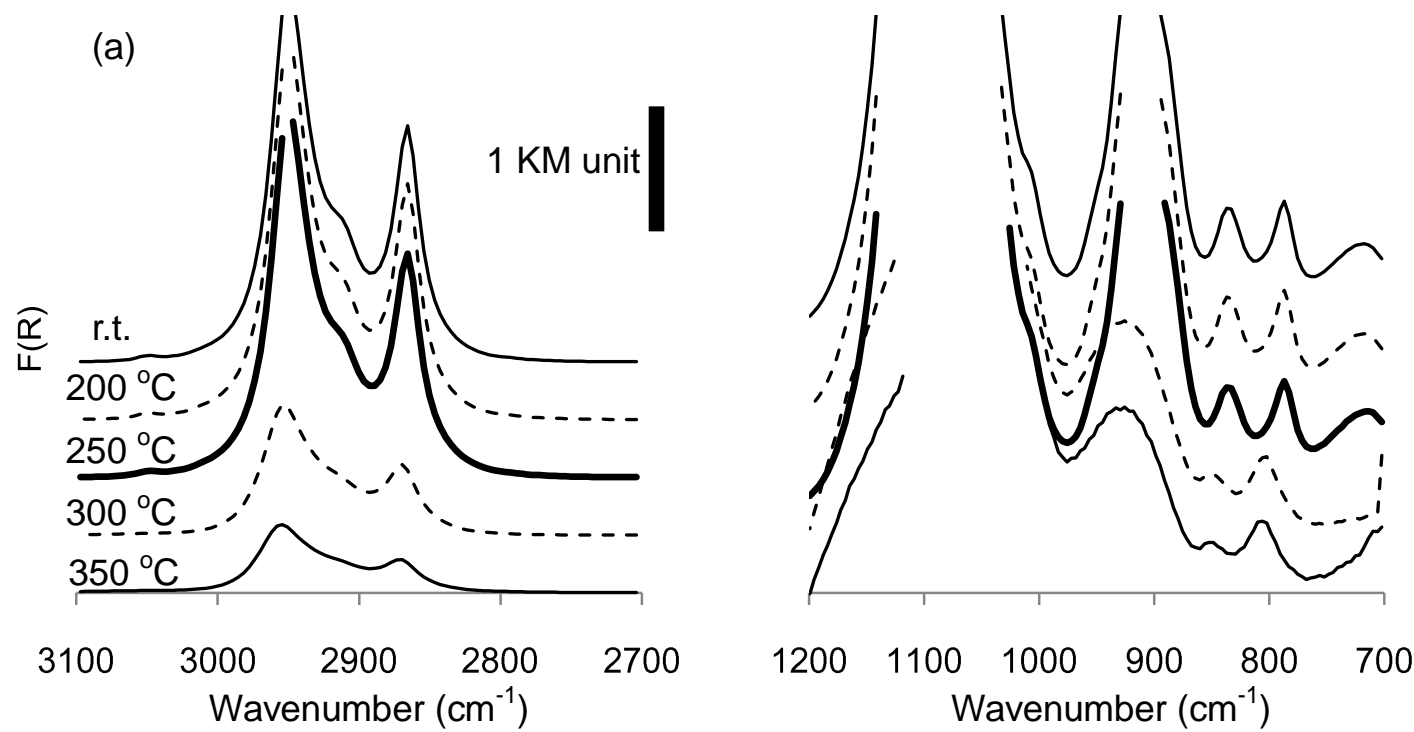

(b)
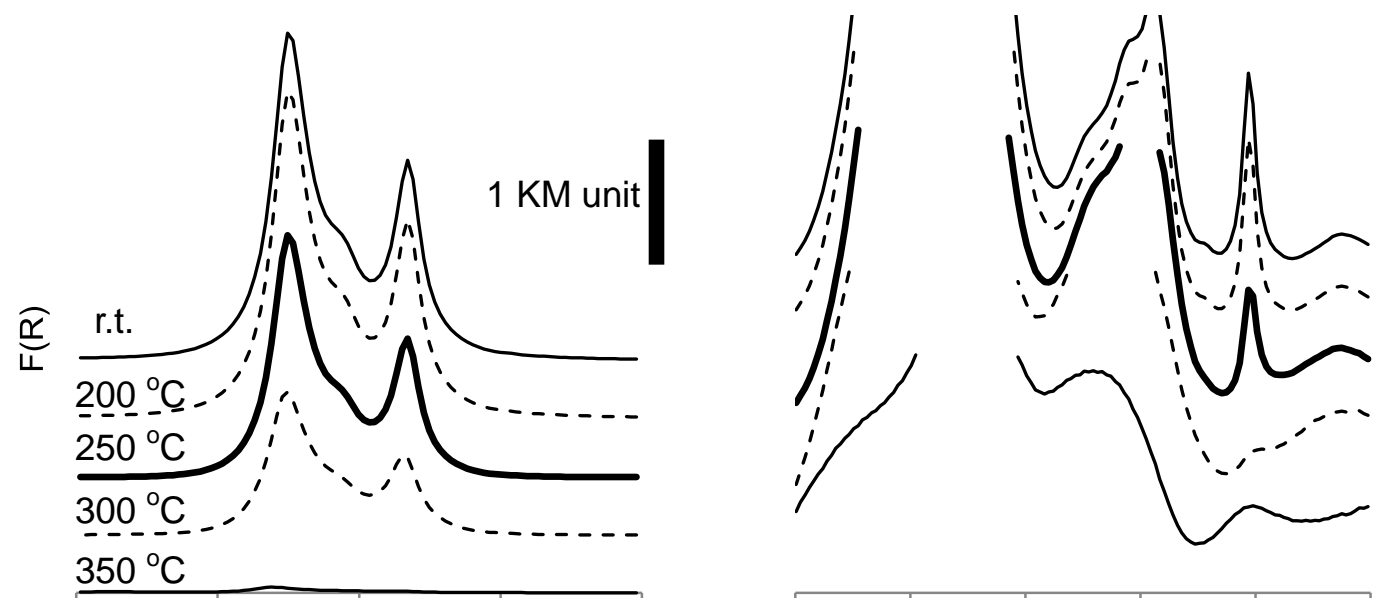

3100

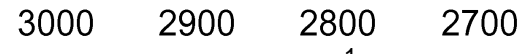

Wavenumber $\left(\mathrm{cm}^{-1}\right)$

$\begin{array}{llllll}1200 & 1100 & 1000 & 900 & 800 & 700\end{array}$ Wavenumber $\left(\mathrm{cm}^{-1}\right)$ 

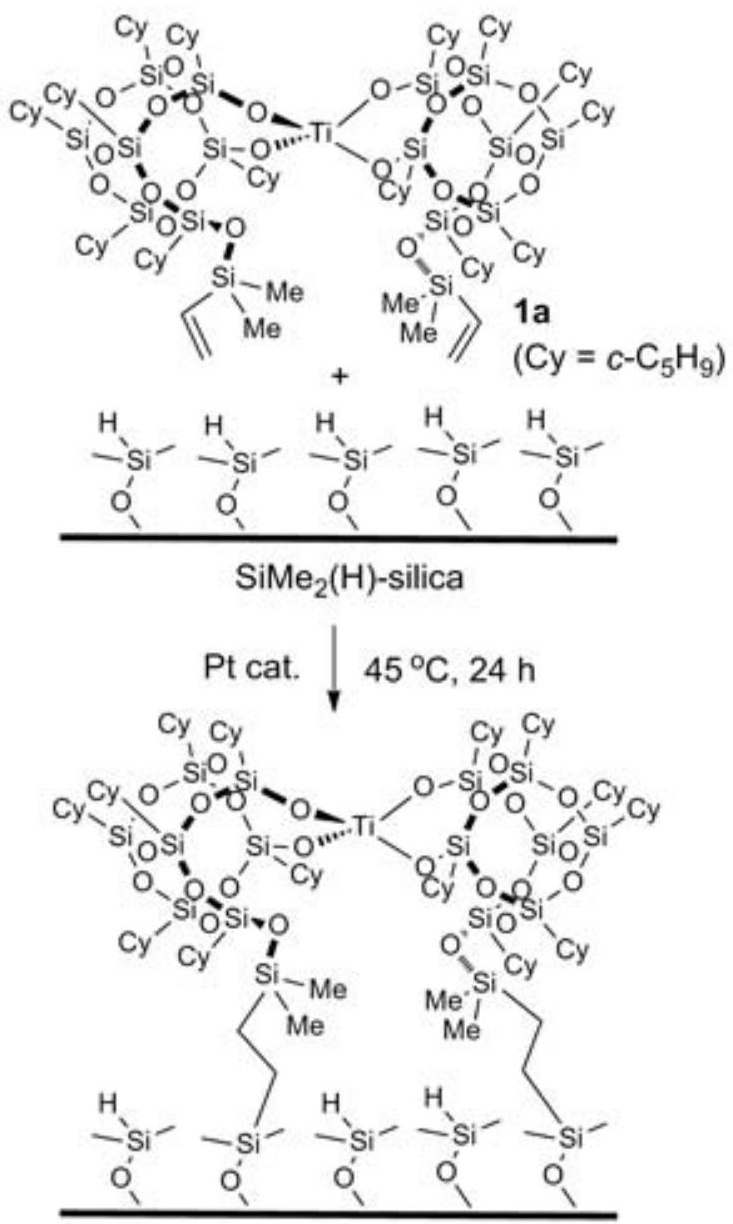

1a-SiMe ${ }_{2}(\mathrm{H})$-silica

in air $\downarrow 550^{\circ} \mathrm{C}, 2 \mathrm{~h}$

1a-SiMe ${ }_{2}(\mathrm{H})$-silica-cal 
